\title{
PENGARUH PEMAHAMAN PERATURAN PERPAJAKAN, TARIF PAJAK, DAN ASAS KEADILAN TERHADAP KEPATUHAN WAJIB PAJAK USAHA MIKRO, KECIL DAN MENENGAH DI KABUPATEN SAMOSIR
}

\author{
IMELDA R. PURBA ${ }^{1}$ \\ LEGAH SARI SIMBOLON ${ }^{2}$ \\ Fakultas Ekonomi Program Studi Akuntansi Universitas Katolik santo Thomas \\ Imelda.rimenda.purba@gmail.com ${ }^{1}$,legahsari@gmail.com ${ }^{2}$
}

\begin{abstract}
ABSTRAK
Penelitian ini bertujuan untuk menguji pengaruh pemahaman peraturan pajak,tarif pajak,dan azas keadilan terhadap kepatuhan wajib pajak usaha mikro , Kecil dan Menengah (UMKM) di kabupaten Samosir. Jenis penelitian ini adalah penelitian kualitatif data yang dipergunakan dalam penelitian ini adalah data primer.Populasi dalam penelitian ini adalah usaha mikro kecil dan menengah,dengan jumlah sampel sebanyak 96 responden,Data diperoleh dari hasil kuesioner yang diisikan kepada responden wajib pajak usaha mikro kecil dan menengah di Kabupaten Samosir.Tehnik pengambilan sampel dalam penelitian ini adalah convenience sampling.Analisa data yang digunakan untuk menguji hipotesis adalah regresi linier berganda, dan pengujian hipotesis menggunakan uji t,uji f dan uji determinasi dengan tingkat significansi 5\%.hasil penelitian ini menunjukkan bahwa variabel pemahaman peraturan pajak tidak berpengaruh terhadap kepatuhan wajib pajak, sedangkan tarif pajak dan azas keadilan secara parsial berpengaruh terhadap kepatuhan wajib pajak.Pemahaman peraturan pajak,tarif pajak dan azas keadilan secara simultan berpengaruh terhadap kepatuhan wajib pajak Usaha Mikro kecil dan menengah di Kabupaten Samosir.
\end{abstract}

kata Kunci: Kepatuhan Wajib Pajak, Pemahaman Peraturan Pajak, Tarif Pajak Dan Asas Keadilan

\section{PENDAHULUAN}

UMKM merupakan usaha yang bersifat padat karya, tidak membutuhkan persyaratan tertentu seperti tingkat Pendidikan, keahlian (keterampilan) pekerja, dan penggunaan modal usaha relatif sedikit serta teknologi yang digunakan cenderung sederhana. UMKM masih memegang peranan penting dalam perbaikan perekonomian Indonesia, baik di tinjau dari segi jumlah usaha, segi penciptaan lapangan kerja, maupun dari segi pertumbuhan ekonomi nasional yang di ukur dengan Produk Domestik Bruto

Pajak adalah iuran kepada Negara yang dapat di paksakan dan terutang oleh yang wajib membayarnya menurut peraturan- peraturan, dengan tidak mendapatkan prestasi kembali yang langsung dapat di tunjuk, gunanya ialah untuk membiayai pengeluaran umum berhubungan dengan tugas Negara untuk menyelenggarakan pemerintahan. Pada dasarnya pajak merupakan pemberian sebagian harta kekayaan rakyat yang digunakan untuk kepentingan bangsa dan Negara. Pembiayaan pembangunan di Indonesia ditopang oleh Negara dari penerimaan pajak. Agar pembangunan terus berjalan dengan baik Oleh karena itu penerapan sistem ini belum bisa meningkatkan kepatuhan perpajakan.

Berikut anggaran dan realisasi penerimaan pajak pada Dinas Pendapatan Daerah Kabupaten Samosir :

Tabel 1. Anggaran Penerimaan Pajak Dan Realisasi Penerimaan Pajak Pada Dinas Pendapatan Daerah Kabupaten Samosir

\begin{tabular}{|c|c|c|}
\hline Tahun & Anggaran (Target) Penerimaan Pajak & Realisasi \\
\hline 2018 & 44.722 .261 .000 & 34.542 .516 .558 \\
\hline
\end{tabular}




\begin{tabular}{|l|l|l|}
\hline 2019 & 40.831 .043 .000 & 68.223 .965 .023 \\
\hline 2020 & 67.059 .024 .000 & 58.852 .750 .592 \\
\hline
\end{tabular}

Sumber: seksi pengolahan data dan informasi Dispenda Kab. Samosir

Tabel 1 menunjukkan bahwa penerimaan PPh tahun 2018 dan 2020 realisasi penerimaan pajak mengalami penurunan dari anggaran penerimaan pajak ini menunjukkan bahwa adanya penurunan kesadaran wajib pajak untuk membayar pajak. Bila wajib pajak sadar akan kewajiban perpajakannya, tentu penerimaan pajak terus meningkat bukan berkurang.

Tabel 2. Jumlah wajib pajak yang melakukan kegiatan usaha dengan tingkat kepatuhan dalam pelaporan SPT tahunan Pada Dispenda Samosir dari tahun 2018-2020

\begin{tabular}{|c|c|c|c|c|}
\hline Tahun & $\begin{array}{l}\text { Jumlah } \\
\text { wajib } \\
\text { pajak }\end{array}$ & $\begin{array}{c}\text { Spt tahunan yang } \\
\text { belum dilaporkan } \\
\text { orang pribadi yang } \\
\text { melakukan } \\
\text { kegiatan usaha }\end{array}$ & $\begin{array}{c}\text { Spt tahunan yang } \\
\text { sudah dilaporkan } \\
\text { orang pribadi } \\
\text { yang melakukan } \\
\text { kegiatan usaha }\end{array}$ & $\begin{array}{c}\text { Tingkat kepatuhan } \\
\text { wajib pajak op yang } \\
\text { melakukan kegiatan } \\
\text { usaha (\%) }\end{array}$ \\
\hline 2018 & 2.125 & 427 & 1.698 & 79,90 \\
\hline 2019 & 2.859 & 492 & 2.367 & 82,79 \\
\hline 2020 & 3.029 & 756 & 2.273 & 75,04 \\
\hline
\end{tabular}

\section{TINJAUAN PUSTAKA DAN PENGEMBANGAN HIPOTESIS}

\section{Pajak sebagai penerimaan Negara}

Pajak adalah "iuran rakyat kepada kas negara berdasarkan undang-undang yang dapat dipaksakan dengan tidak mendapat jasa timbal (Kontraprestasi) yang langsung dapat ditunjukkan dan yang digunakan untuk membayar pengeluaran umum"Pajak berfungsi sebagai sumber dana untuk pengeluaran pemerintah serta sarana untuk melaksanakan kebijakan sosial dan ekonomi (Mardiasmo, 2013:3).

\section{Pemahaman Peraturan Perpajakan}

Pemahaman adalah segala sesuatu yang kita pahami dan kita mengerti dengan benar. Pemahaman adalah bagaimana seseorang mempertahankan, membedakan, menduga, menerangkan, memperluas, menyimpulkan, menggeneralisaikan, memberikan contoh, menuliskan kembali dan memperingatkan". Kemampuan untuk menghubungkan semua bagian dalam peraturan perpajakan menjadi satu pemahaman utuh,k emampuan melihat dampak dan konsekuensi atas peraturan perpajakan yang diketahui secara utuh, sehingga mampu memperluas pandangan terhadap perpajakan, serta implikasi yang ditimbulkannya

\section{Tarif Pajak}

Tarif merupakan persentase/ jumlah yang di bayar wajib pajak sesuai dengan penghasilan yang dihasilakan oleh wajib pajak. Dampak dari besarnya tarif dan besarnya penghasilan jika ada perubahan maka besarnya pajak terutang juga akan berubah jumlahnya (Mardiasmo, 2011). Tarif PPh Final sebesar 0,5 \% hanya berlaku untuk UMKM yang memiliki peredaran bruto (omzet) tidak melebihi $\mathrm{Rp} 4,8$ miliar dalam satu tahun pajak. Untuk UMKM konvensional atau offline maupun yang berjualan di toko online (marketplace dan media social). Terdiri dari tarif tetap,tarif proporsional dan dan tarif progresif.

4. Asas Keadilan Pajak

Prinsip asas keadilan (equality) merupakan salah satu dari prinsip utama dalam rangka pemungutan pajak, yang menjelaskan bahwa setiap warga Negara berpartisipasi dalam pembiayaan fungsi pemerintah suatu negara, secara proporsional sesuai dengan kemampuan masing-masing. Menurut Siti kurnia rahayu 2020, asas keadilan adalah 
dimana dalam pemungutan pajak terdapat

\section{Kepatuhan perpajakan}

Kepatuhan perpajakan meliputi kepatuhan perpajakan formal dan kepatuhan perpajakan material. Kepatuhan perpajakan formal merupakan ketaatan wajib pajak dalam memenuhi ketentuan formal perpajakan, yakni tepat waktu mendaftar, menyetor dan melapor pajaknya. Kepatuhan perpajakan formal merupakan ketaatan wajib pajak dalam memenuhi ketentuan material perpajakan,yakni tepat menghitung, tepat memotong Perkembangan Usaha Mikro Kecil Menengah

\section{Kerangka Berpikir}

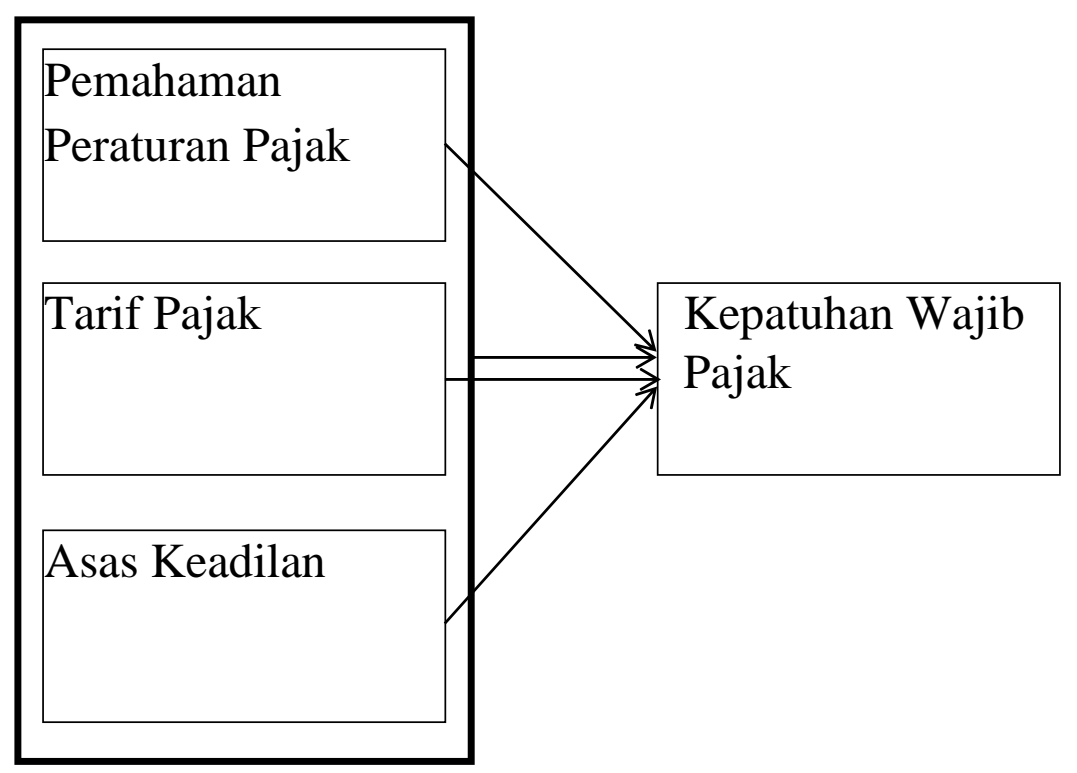

Gambar 1. Kerangka Pikir

Pengaruh pemahaman peraturan perpajakan terhadap kepatuhan wajib pajak UMKM. Pemahaman pajak dilihat dari perspektif hukum merupakan suatu berikatan yang timbul karena adanya Undang-undang yang menyebabkan timbulnya kewajiban warga negara untuk menyetorkan sejumlah penghasilan tertentu kepada negara. Negara mempunyau kekuatan untuk memaksa dan uang pajak tersebut harus dipergunakan untuk penyelenggaraan pemerintah. Dari pendekatan hukum ini memperlihatkan bahwa pajak yang dipungut harus berdasarkan Undang-undang sehingga menjamin adanya kepastian hukum, baik bagi fiskus sebagai pengumpul pajak maupun wajib pajak sebagai pemabayar pajak.

\section{Pengaruh tarif pajak terhadap kepatuhan wajib pajak UMKM}

Tarif ini dimaksudkan agar pelaku UMKM tidak terbebani dengan tarif pajak yang tinggi. Selain itu, melalui kebijakan ini diharapkan meningkat partisipasi pelaku usaha Mikro Kecil Menengah untuk berperan aktif sebagai wajib pajak dalam memenuhi kepatuhannya sebagai wajib pajak (Siti Kurnia, 2020).

\section{Pengaruh asas Keadilan terhadap kepatuhan wajib pajak}

Asas keadilan ini harus senantiasa di pegang teguh, baik dalam prinsip mengenai undangundang maupun dalam praktek sehari-hari. Asas keadilan dalam meningkatkan kepatuhan perpajakan dalam sistem perpajakan di suatu Negara akan memberikan efek positif terhadap tingkat kepatuhan wajib pajak dalam melakukan pemenuhan kewajiban perpajakan, sehingga akan menimbulkan peningkatan penangguhan pajak. 


\section{METODOLOGI PENELITIAN}

\section{Populasi dan Sampel}

Populasi dalam penelitian ini adalah seluruh pengusaha Usaha Mikro, Kecil Menengah yang terdaftar pada Badan Pendapatan Daerah Kabupaten Samosir. Sampel adalah bagian populasi yang akan dipelajari secara detail (sekarn, 2006). Untuk menentukan sampel penelitian dugunakan rumus Slovin.

Berdasarkan hasil perhitungan diatas, diketahui Populasi sebesar 3.029 dan sampel penelitian sebanyak 96 orang. Menurut Sugiyono (2010:118) Teknik penentuan sampel adalah convenience sampling, yaitu pengambilan sampel dilakukan dengan pertimbangan tertentu.

\section{Operasional Variabel}

Operasional variabel merupakan penjelasan suatu variabel ke dalam indikator yang lbh terperinci, sehingga variabel tersebut dapat diketahui ukurannya. Dalam penelitian ini dilakukan analisis pada besarnya pengaruh tiga variabel bebas dan satu variabel terikat atau pemahaman peraturan perpajakan, tarif pajak, asas keadilan berpengaruh signifikan terhadap kepatuhan wajib pajak. Variabel yang terdapat dalam penelitian ini terdiri atas variabel bebas dan variabel terikat yaitu :

\section{a.Variabel Independen $(\mathbf{X})$}

Variabel independen dalam penelitiaan ini adalah variabel pemahaman peraturan pajak,tarif pajak dan asas keadilan.

\section{Variabel Pemahaman Peraturan pajak}

Indikator pemahaman peraturan perpajakan, yaitu Kemampuan dalam menjelaskan, dan mengartikan peraturan perpajakan, Kemampuan mendeskripsikan, dan mengklasifikasikan peraturan perpajakan, sehingga dapat memberikan contoh-contoh kasus perpajakan, Kemampuan menerjemahkan dan menyimpulkan peraturan perpajakan.

Variabel ini diukur dengan Skala Likert, dalam penelitian ini masing- masing jawaban pertanyaan dalam kuesioner diberi skor sebagai berikut :

Tabel 3. Pemahaman Peraturan Pajak

\begin{tabular}{|c|l|l|l|l|l|}
\hline No & \multicolumn{1}{|c|}{ Pertanyaan SS } & S & R & TS & STS \\
\hline 1 & $\begin{array}{l}\text { Setujukan saudara setiap wajib Pajak } \\
\text { mendaftarkan diri untuk memperoleh NPWP dengan } \\
\text { syarat memiliki ID }\end{array}$ & & & & \\
\hline 2 & $\begin{array}{l}\text { Setujukan saudara setiap Wajib Pajak Harus } \\
\text { Mengetahui Hak dan Kewajiban nya }\end{array}$ & & & & \\
\hline 3 & $\begin{array}{l}\text { Setujukan saudara manfaat membayar pajak salah } \\
\text { satunya adalah menyediakan sarana pendidikan dan } \\
\text { layanan kesehatan gratis yang disediakan } \\
\text { Pemerintah }\end{array}$ & & & & \\
\hline 4 & $\begin{array}{l}\text { Apakah Saudara setuju pemahaman } \\
\text { peraturan perpajakan diperoleh melalui alat } \\
\text { media, sosialisasi dan Training }\end{array}$ & $\begin{array}{l}\text { Setujukah saudara pajak yang di bayar dihitung } \\
\text { berdasarkan penghasilan netto dikurangi PTKP } \\
\text { kemudian dikalikan dengan } \\
\text { tarif yang berlaku }\end{array}$ & & & \\
\hline
\end{tabular}




\begin{tabular}{|c|c|c|c|c|c|c|}
\hline No & Pertanyaan & SS & S & R & TS & STS \\
\hline 6 & $\begin{array}{l}\text { Apakah saudara setuju jika tidak } \\
\text { melaksanakan kewajiban akan dikenakan sanksi }\end{array}$ & & & & & \\
\hline
\end{tabular}

\section{Variabel Tarif Pajak (X2)}

Tarif pajak adalah jumlah yang digunakan untuk menentukan kewajiban pajak yang harus dibayar oleh wajib pajak. Tarif merupakan jumlah yang di bayar wajib pajak sesuai dengan penghasilan yang dihasilkan wajib pajak.

Tarif pajak sebagai dasar pengenaan pajak untuk menentukan jumlah pajak terutang. Peraturan pemerintah no 23 Tahun 2018 dengan tarif final 0,5\% dapat meringankan wajib pajak UMKM dalam membayar pajak. Variabel ini diukur dengan Skala Likert, dalam penelitian ini masing- masing jawaban pertanyaan dalam kuesioner diberi skor sebagai berikut:

Tabel 4. Tarif Pajak

\begin{tabular}{|c|l|l|l|l|l|}
\hline No & \multicolumn{1}{|c|}{ Pertanyaan } & SS & R & TS & STS \\
\hline 1 & $\begin{array}{l}\text { Setuju kah saudara bahwa tarif pajak adalah dasar } \\
\text { pengenaan pajak untuk menentukan jumlah pajak } \\
\text { terutang }\end{array}$ & & & & \\
\hline 2 & $\begin{array}{l}\text { Setujukan saudara Penurunan Tarif UMKM dari 10\% } \\
\text { menjadi 5 \% dapat Meningkatkan Kepatuhan Dalam } \\
\text { membayar pajak }\end{array}$ & & & & \\
\hline 3 & $\begin{array}{l}\text { Apakah saudara setuju Tarif Pajak saat Ini lebih baik } \\
\text { dari tarif pajak sebelum nya }\end{array}$ & & & & \\
\hline 4 & $\begin{array}{l}\text { Setujukan saudara penurunan tarif akan berdampak } \\
\text { pada jumlah pajak terutang }\end{array}$ & & & & \\
\hline 5 & $\begin{array}{l}\text { Setujukah saudara Penetapan tarif Pajak tanpa melihat } \\
\text { Penghasilan untung dan rugi dapat merugikan wajib } \\
\text { Pajak }\end{array}$ & & & \\
\hline
\end{tabular}

\section{Variabel Asas Keadilan (X3)}

Menurut Siti Rahayu Kurnia (2020) asas keadilan perpajakan dalam sistem perpajakan di suatu Negara akan memberikan efek positif terhadap tingkat kepatuhan wajib pajak dalam memenuhi kewajiban perpajakan, sehingga akan menimbulkan peningkatan penerimaan pajak. Asas Keadilan perpajakan dapat dilihat dari indikator Adil dalam perundang-undangan dan adil dalam pelaksanaan

Tabel 5. Asas Keadilan

\begin{tabular}{|c|l|l|l|l|l|l|}
\hline No & Pertanyaan & SS & S & R & TS & STS \\
\hline 1 & $\begin{array}{l}\text { Setuju kah saudara pengenaan pajak secara umum dan } \\
\text { merata }\end{array}$ & & & & \\
\hline 2 & $\begin{array}{l}\text { Setujukah saudara hak wajib pajak untuk mengajukan } \\
\text { keberatan penundaan dalam pembayaran }\end{array}$ & & & & \\
\hline
\end{tabular}




\begin{tabular}{|c|l|l|l|l|l|}
\hline No & \multicolumn{1}{|c|}{ Pertanyaan } & SS & S & TS & STS \\
\hline 3 & $\begin{array}{l}\text { Setujukah saudara dalam suatu Negara tidak } \\
\text { diperbolehkan melakukan diskriminasi sesame wajib } \\
\text { pajak }\end{array}$ & & & & \\
\hline 4 & $\begin{array}{l}\text { Setujukan saudara mempunyai hak untuk menunda } \\
\text { pembayaran }\end{array}$ & & & & \\
\hline 5 & $\begin{array}{l}\text { Biaya pemungutan pajak hendaknya seminimal } \\
\text { mungkin }\end{array}$ & & & & \\
\hline 6 & $\begin{array}{l}\text { Setuju kah saudara pemungutan pajak harus sesuai } \\
\text { dengan undang-undang }\end{array}$ & & & \\
\hline
\end{tabular}

\section{b. Variabel Dependen (Y) Kepatuhan Wajib Pajak}

Dalam penelitian ini, variabel terikat "kepatuhan wajib pajak adalah kepatuhan wajib pajak untuk mendaftarkan diri, kepatuhan untuk menyetor Kembali SPT, kepada dalam perhitungan dan pembayaran pajak terutang, kepatuhan dalam pembayaran tunggakan“.

Variabel ini diukur dengan Skala Likert, dalam penelitian ini masing- masing jawaban pertanyaan dalam kuesioner diberi skor sebagai berikut :

Tabel 5 Kepatuhan Wajib Pajak

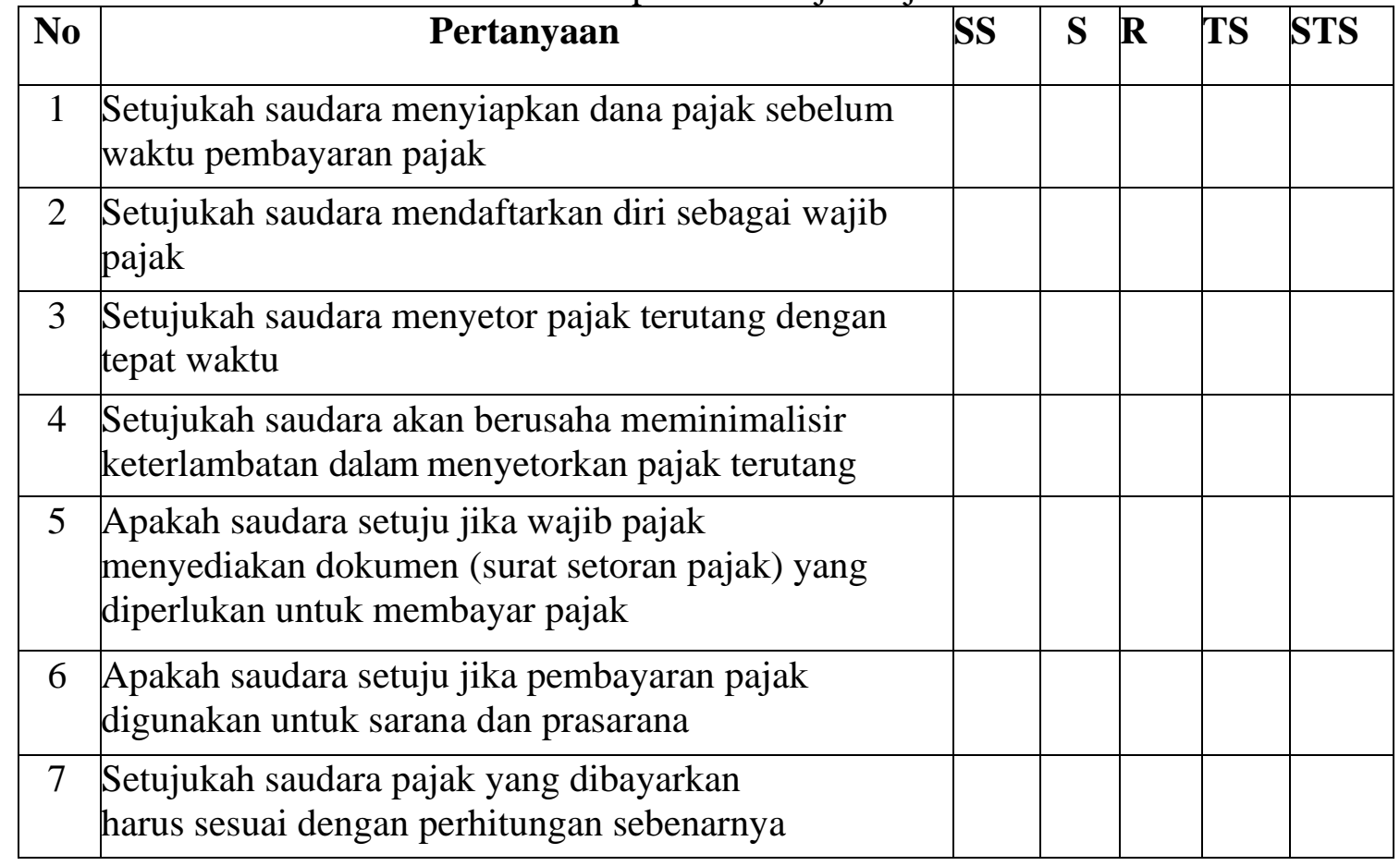

\section{Teknik Pengumpulan Data}

Data utama penelitian ini diperoleh melalui penelitian lapangan, data langsung dari pihak pertama. Yang menjadi subjek penelitian adalah pengusaha UMKM. Data yang penulis kumpulkan khususnya data kuisioner kemudian akan di proses melalui uji statistik. Prosedur metode kuesioner adalah peneliti akan memberikan sejumlah pertanyaan kepada pengusaha UMKM dinas Kabupaten Samosir dengan menggunakan media angket sebagai berikut :

$$
\begin{array}{cl}
\text { No } & \text { Jenis Jawaban } \\
1 & \text { SS = Sangat Setuju }
\end{array}
$$

\section{Bobot}




$\begin{array}{lll}2 & \text { S =Setuju } & 4 \\ 3 & \text { R =Ragu-Ragu } & 3 \\ 4 & \text { TS=Tidak Setuju } & 2 \\ 5 & \text { STS =Sangat Tidak Setuju } & 1\end{array}$

\section{Teknik Analisi Data}

Analisis data yang digunakan dalam mengelolah data yang diperoleh sehingga didapatkan suatu hasil analisi atau hasil uji. Data-data yang diperoleh dari penelitian tidak dapat digunakan secara langsung, tetapi perlu diolah lebih dulu agar data tersebut dapat memberikan keterangan yang dapat dipahami, jelas dan teliti.

\section{Uji Kualitas Data}

Untuk mengetahui kuesioner berkualitas dilakukan uji validitas dan reliabilitas serta uji Asumsi Klasik. Penjelasan ketiga uji tersebut sebagai berikut :

\section{Uji Validitas}

Pengujian validitas dilakukan untuk membuktikan sejauh mana data yang terdapat dalam kuesioner dapat mengukur senyatanya (actually) dan seakuratnya (accurately). Suatu kuesioner dikatakan valid jika pertanyaan pada kuesioner mampu untuk mengungkapkan sesuatu yang akan diukur oleh kuesioner tersebut. Pengujian validitas dilakukan dengan bantuan program SPSS versi 26 dengan metode pearson correction,

\section{Uji Reliabilitas}

Suatu Kuesioner dikatakan reliabel atau handal jika jawaban seseorang terhadap pertanyaan adalah konsisten atau stabil dari waktu ke waktu. Teknik yang digunakan dalam penelitian ini adalah dengan mengukur koifisien

\section{Uji Asumsi Klasik}

Untuk melakukan uji asumsi klasik pada data primer, maka dilakukan uji normalitas, uji multikolonieritas, dan uji heteroskedastisitas.

\section{Uji Normalitas}

Uji normalitas data dilakukan untuk melihat bahwa suatu data terdistribusi secara normal atau tidak. Uji normalitas data dilakukan dengan menggunakan histogram standardized residual dan PP plot satndardizer residual. (Ghozali, 2006) dasar untuk mengambil keputusan adalah sebabgai berikut :Apabila histogram standardized residual membentuk kurva normal maka data berdistribusi normal.

\section{Uji Multikolinieritas}

Uji multikolinearita bertujuan untuk mengetahui apakah terdapat interkorelasi yang sempurna diantara beberapa variabel bebas yang digunakan dalam model. Multikolinieritas terjadi jika terdapat hubungan linier antara variabel independen yang dilibatkan dalam model. Jika terjadi gejala multikolineritas yang tinggi, standart error koifisien regresi akan semakin besar dan mengakibatkan confidence interval untuk pendugaan parameter semakin lebar, dengan demikian terbuka kemungkinan terjadinya kekeliruan, menerima hipotesis yang salah.

Model regresi yang baik seharusnya tidak terjadi korelasi diantara variabel bebasnya, (Ghozali, 2006)

\section{Uji Heteroskedastisitas}

Uji Heteroskedastisitas bertujuan untuk menguji apakah dalam model regresi terjadi ketidaksamaan variabel dari residual satu pengamatan ke pengamataan lain. Jika varian dari 
residual satu pengamatan ke pengamatan lain tetap, maka disebut okedasti dan jika berbeda disebut Heteroskedastisitas. (Ghozali, 2006). Metode yang digunakan dalam penelitian ini adalah dengan grafik plot.

\section{Regresi Linier Berganda}

Pengujian regresi linier berganda digunakan untuk memprediksikan nilai dari variabel dependen dengan adanya perubahan dari variabel independent. Dalam penelitian menggunakan analisis regresi linier berganda yaitu model regresi untuk menganalisis lebih dari satu variabael independent. Persamaan regresi yang di rumuskan berdasarkan hipotesis yang dikembangkan adalah sebagai berikut :

$$
\text { Keterangan : } \begin{aligned}
\mathrm{Y}= & \mathbf{Y}=\mathbf{\alpha}+\mathbf{b} \mathbf{X} \mathbf{X}+\mathbf{b} \mathbf{X} \mathbf{2}+\mathbf{b} \mathbf{3 X} \mathbf{3}+\mathbf{e} \\
& \text { Variabel terikat (dependent) } \\
\alpha= & \text { nilai konstanta } \\
\mathrm{b} 1= & \text { Koifisien Regresi untuk variabel X1 } \\
\mathrm{b} 2= & \text { Koifisien Regresi untuk variabel X2 } \\
\mathrm{b} 3= & \text { Koifisien Regresi untuk variabel X3 } \\
\mathrm{X}= & \text { Variabel Bebas (Independen) } \\
\mathrm{e}= & \text { Eror (Faktor Pengangguran/residual) }
\end{aligned}
$$

\section{Pengujian Hipotesis}

Uji hipotesis dalam penelitian ini menggunakan analisis regresi berganda, uji koifisien determinasi dan uji statistik t. persamaan regresi bertujuan untuk memprediksi variabel terikat yaitu kepatuhan wajib pajak UMKM dengan menggunakan data variabel bebas yaitu, pemahaman peraturan perpajakan, tarif pajak, asas keadilan.

\section{Uji (Koeifisien Determinasi)}

Uji koeifisien determinasi digunakan untuk menentukan seberapa besar variabel independen dapat menjelaskan variabel dependen, nilai koifisien determinasi antara nol dan satu. Nilai yang lebi kecil berarti kemampuan variabel-variabel independent dalam menjelaskan variabel dependen amat terbatas.

\section{Uji Secara Parsial (uji t)}

Uji t digunakan untuk mengetahui pengaruh dari tingkat pemahaman peraturan pajak, tarif pajak dan asas keadilan secara parsial terhadap kepatuhan wajib pajak UMKM wilayah Kabupaten Samosir.

\section{Uji secara Simultan (Uji F)}

Uji F dilakukan untuk melihat pengaruh dari tingkat pemahaman peraturan perpajakan, tarif pajak, dan asas keadilan perpajakan secara simultan terhadap kepatuhan wajib pajak pengusaha UMKM wilayah Kabupaten Samosir.Langkah-langkah pengujian yang dilakukan adalah sebagai berikut :

\section{HASIL PENELITIAN DAN PEMBAHASAN}

\section{Gambaran Umum Responden}

Responden dalam penelitian ini yaitu wajib pajak orang pribadi yang melakukan kegiatan usaha yang terdaftar pada Badan pendapan Daerah Kabupaten Samosir dengan Jumlah responden sebanyak 96 orang. 96 eksamplar kuesioner yang diberikan kepada responden telah diisi secara lengkap dan benar sehingga layak untuk dianalisis lebih lanjut untuk kepentingan penelitian ini. Karakteristik responden dikelompokkan menurut jenis kelamin, usia, dan 
tingkat pendidikan.

Tabel 6 Karakteristik dan Gambaran Umum Responden

\begin{tabular}{|l|c|c|r|}
\hline \multirow{4}{*}{$\begin{array}{c}\text { DATA } \\
\text { DESKRIPTIF }\end{array}$} & KETERANGAN & JUMLAH & $\begin{array}{c}\text { PERSENTASE } \\
(\mathbf{\%})\end{array}$ \\
\hline \multirow{3}{*}{ Jenis kelamin } & pria & 52 & $54 \%$ \\
\cline { 2 - 4 } & Wanita & 44 & $46 \%$ \\
\hline \multirow{4}{*}{ Usia } & $7-25$ tahun & 10 & $10 \%$ \\
\cline { 2 - 4 } & $26-40$ tahun & 31 & $32 \%$ \\
\cline { 2 - 4 } & $41-45$ tahun & 39 & $41 \%$ \\
\cline { 2 - 4 } & $>55$ tahun & 16 & $17 \%$ \\
\hline \multirow{4}{*}{ tingkat pendidikan } & SD & 10 & $10 \%$ \\
\cline { 2 - 4 } & SMP & 22 & $23 \%$ \\
\cline { 2 - 4 } & SMA & 24 & $25 \%$ \\
\cline { 2 - 4 } & D3 & 18 & $19 \%$ \\
\cline { 2 - 4 } & S1 & 11 & $11 \%$ \\
\cline { 2 - 4 } & S2 & 11 & $11 \%$ \\
\hline
\end{tabular}

Sumber : Data Primer Yang Diolah (2021)

\section{Uji Kualitas Data}

\section{Uji Validitas}

Uji validitas dilakukan untuk mengatahui apakah suatu pernyataan yang digunakan dalam pemahaman, tarif pajak dan asas keadilan peraturan perpajakan valid. Butir pertanyaan yang valid relevan digunakan sebagai indikator pengukur variabel, sedangkan butir pertanyaan dari kuesioner yang tidak valid kurang relevan digunakan sebagai indikator pengukur variabel.

Tabel 7 Uji Validitas Varibel Pemahaman Peraturan Pajak

\begin{tabular}{|c|c|c|}
\hline Butir Pertanyaan & r hitung & Keterangan \\
\hline Pertanyaan 1 & 0.623 & Valid \\
\hline Pertanyaan 2 & 0.679 & Valid \\
\hline Pertanyaan 3 & 0.552 & Valid \\
\hline Pertanyaan 4 & 0.577 & Valid \\
\hline Pertanyaan 5 & 0.752 & Valid \\
\hline Pertanyaan 6 & 0.499 & Valid \\
\hline
\end{tabular}

Sumber: Pengolahan Data SPSS IBM 26

Tabel 8 Hasil Uji Validitas Variabel Tarif Pajak

\begin{tabular}{|c|c|c|}
\hline Butir Pertanyaan & r hitung & Keterangan \\
\hline Pertanyaan 1 & 0.567 & Valid \\
\hline Pertanyaan 2 & 0.892 & Valid \\
\hline Pertanyaan 3 & 0.700 & Valid \\
\hline Pertanyaan 4 & 0.842 & Valid \\
\hline Pertanyaan 5 & 0.859 & Valid \\
\hline
\end{tabular}

Sumber : Pengolahan Data SPSS IBM 26 
Tabel 9 Hasil Uji Validitas Variabel Asas Keadilan

\begin{tabular}{|l|c|c|}
\hline Butir pertanyaan & r hitung & Keterangan \\
\hline Pertanyaan 1 & 0.726 & Valid \\
\hline Pertanyaan 2 & 0.625 & Valid \\
\hline Pertanyaan 3 & 0.553 & Valid \\
\hline Pertanyaan 4 & 0.502 & Valid \\
\hline Pertanyaan 5 & 0.702 & Valid \\
\hline Pertanyaan 6 & 0.352 & Valid \\
\hline
\end{tabular}

Sumber: pengolahan Data SPSS IBM 26

Tabel 10 Hasil Uji Validitas Variabel Kepatuhan Wajib Pajak

\begin{tabular}{|c|c|c|}
\hline Butir Pertanyaan & r hitung & Keterangan \\
\hline Pertanyaan 1 & 0.206 & Valid \\
\hline Pertanyaan 2 & 0.713 & Valid \\
\hline Pertanyaan 3 & 0.793 & Valid \\
\hline Pertanyaan 4 & 0.593 & Valid \\
\hline Pertanyaan 5 & 0.525 & Valid \\
\hline Pertanyaan 6 & 0.555 & Valid \\
\hline Pertanyaan 7 & 0.858 & Valid \\
\hline
\end{tabular}

Sumber : Pengolahan Data SPSS IMB 26

\section{Uji Reliabilitas}

Uji reliabilitas ini dilakukan dengan menggunakan metode uji statistik cronbach's Alpha (koifisien keandalan) yaitu koifisien reliabilitas yang menunjukkan seberapa baik item atau instrumen berkorelasi positif dengan item lainnya. Semakin tinggi Alpha berarti semakin baik pengukuran suatu instrumen. Variabel dikatakan andal (reliabel) jika memberikan nilai cronbach's Alpha > r tabel (Ghozali, 2006). Berdasarkan analisis uji reliabilitas menggunakan SPSS 26 diperoleh hasil sebagai berikut:

Tabel 11 Hasil Uji Reliabilitas

\begin{tabular}{|l|c|c|}
\hline \multicolumn{1}{|c|}{ Variabel } & Cronbach's Alpha & Keterangan \\
\hline Pemahaman Peraturan Pajak (X1) & 0.665 & Reliabel \\
\hline Tarif Pajak (X2) & 0.825 & Reliabel \\
\hline Asas Keadilan (X3) & 0.598 & Reliabel \\
\hline Kepatuhan Wajib Pajak (Y) & 0.696 & Reliabel \\
\hline
\end{tabular}

Sumber : Pengolahan Data SPSS IBM 26

\section{Pengujian Asumsi Klasik}

\section{Uji Normalitas Data}

Pengujian ini bertujuan untuk mengetahui apakah dalam sebuah regresi, variabel dependen, variabel independen atau keduanya mempunyai distribusi normal atau tidak. Model regresi yang baik adalah distribusi data masing-masing variabel nya normal atau mendekati normal. Berdasarkan grafik histogram, dapat dilihat bahwa gambar histogram telah berbentuk lonceng dan tidak menceng ke kanan atau ke kiri yang menunjukkan bahwa data telah terdistribusi secara normal. 


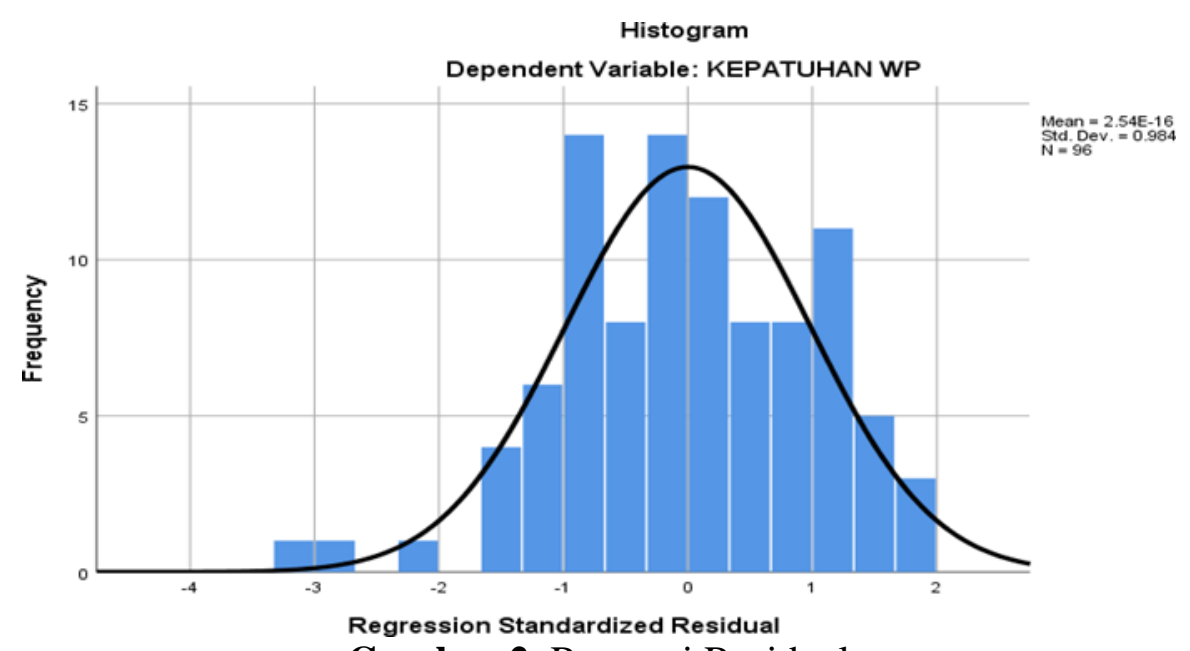

Gambar 2. Regressi Residual

Sumber : Pengolahan Data SPSS IBM 26

Dari gambar 2 terlihat bahwa grafik histogram memberikan pola distribusi yang mendekati normal. Dengan demikian sampel tersebut memenuhi syarat untuk dilakukan penelitian lebih lanjut.

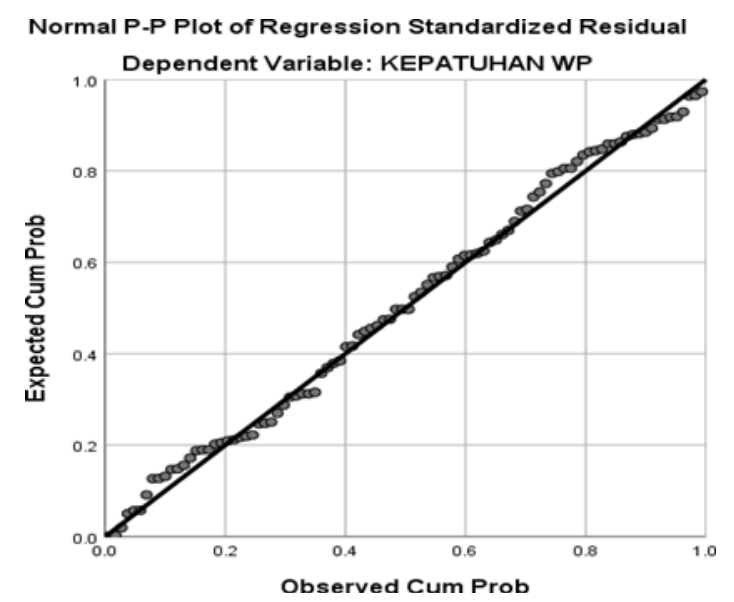

Gambar 3 Uji Normalitas

Sumber : Pengolahan Data SPSS IBM 26

\section{Uji Heterokedastisitas}

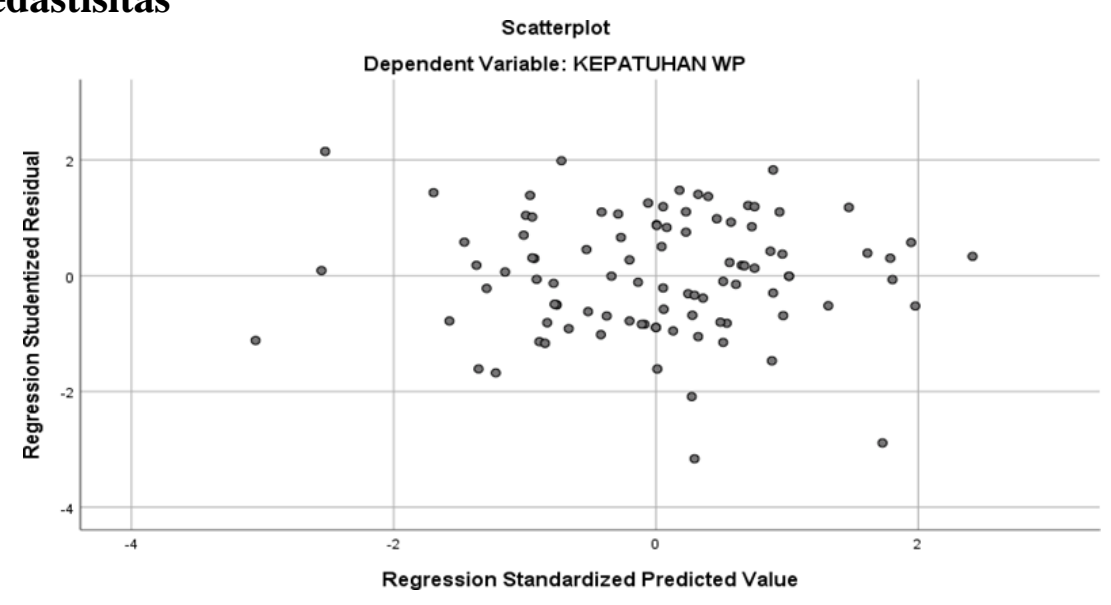

Gambar 3 Uji Heterokedastisitas

Sumber: Pengolahan Data SPSS IMB 26 


\section{Uji Multikolinearitas}

Uji multikolinearita dimaksudkan untuk mengetahui korelasi linier antara dua atau lebih variabel independen yang digunakan dalam penelitian ini. Uji ini dilakukan dengan tolerance Value dan Variance Inflation Factor (VIF). Agar tidak terjadi multikolinearitas batas tolerance Value $>0.10$ dan VIF $<10$. Adapun hasil uji multikolinearitas pada penelitian ini dapat dilihat pada tabel berikutini.

Tabel 12 Hasil Uji Multikolinearitas

\begin{tabular}{|c|c|r|}
\hline \multirow{2}{*}{ Model } & Collinearity statistics \\
\cline { 2 - 3 } & Tolerance & VIF \\
\hline (constant) & & 1.284 \\
\hline Pemahaman peraturan pajak & .779 & 1.429 \\
\hline Tarif pajak & .700 & 1.149 \\
\hline Asas keadilan & .872 & \\
\hline
\end{tabular}

a. $\quad$ Variabel dependen:Kepatuhan Wajib Pajak

Sumber:Pengolahan Data SPSS IBM 26

\section{Hasil Regresi Linier Berganda}

Hasil uji regresi linier berganda terhadap tiga variabel independen, yaitu pemahaman peraturan pajak, tarif pajak dan asas keadilan dapat dilihat pada tabel 12 berikut ini.

Tabel 12 Hasil Uji Analisis Regresi Linier berganda

\begin{tabular}{|c|c|c|}
\hline \multirow{3}{*}{ Model } & \multirow{2}{*}{\multicolumn{2}{|c|}{ Unstardized Coefficients }} \\
\hline & & \\
\hline & $\mathbf{B}$ & Std Error \\
\hline (constant) & 10.402 & 2.328 \\
\hline Pemahaman peraturan pajak & -0.185 & 126 \\
\hline Tarif Pajak & 0.395 & 120 \\
\hline Asas Keadilan & 0.282 & 120 \\
\hline
\end{tabular}

a. Variabel Dependen:Kepatuhan Wajib Pajak

Sumber:Pengolahan Data SPSS IBM 26

Berdasarkan tabel tersebut, maka persamaan regresi yang terbentuk adalah sebagai berikut :

$$
\mathrm{Y}=10.402-185 \mathrm{PP}+395 \mathrm{TF}+282 \mathrm{AK}+\mathrm{e}
$$

Dimana:

$\mathrm{Y} \quad=$ Kepatuhan Wajib Pajak

$\mathrm{X} 1=$ Pemahaman peraturan pajak X2 = Tarif Pajak

$\mathrm{X} 3$ = Asas Keadilan

Dari persamaan di atas dapat di artikan sebagai berikut:

1. Nilai konstanta sebesar 10.402 menunjukkan bahwa jika variabel-variabel independen (pemahaman peraturan pajak, tarif pajak dan asas keadilan) bernilai 0, maka nilai Y (kepatuhan wajib pajak) akan tetap sebesar 10,402

2. Makna koefisien regresi berganda pemahaman peraturan pajak (X1) berpengaruh negatif terhadap kewajiban perpajakan. Hal ini dapat dilihat dari nilai koefisien regresi yang bertanda negatif.

\section{Pengujian Hipotesis}

\section{Uji Koefisien Determinasi}

Untuk mengetahui persentase sumbangan pengaruh variabel independen (pemahaman 
peraturan pajak, tarif pajak dan asas keadilan) secara serentak terhadap variabel dependen (kepatuhan wajib pajak). Ini menunjukkan seberapa besar persentase variasi variabel dependen, koefisien dapat dilihat pada tabel berikut:

Tabel 13 Hasil Uji Koefisien Determinasi ( )

Model Summary

\begin{tabular}{|c|c|c|c|l|}
\hline Model & R & R square & $\begin{array}{l}\text { Adjusted R } \\
\text { Square }\end{array}$ & $\begin{array}{l}\text { Std. Error Of } \\
\text { the Estimate }\end{array}$ \\
\hline 1 & $0.464 \mathrm{a}$ & 215 & 189 & 2.868 \\
\hline
\end{tabular}

a. Predictors: (Constant), X3, X1, X2

Sumber: Pengolahan Data SPSS IBM 26

Berdasarkan tabel 10 model Summary, diperoleh nilai adjusted sebesar 0.215 hal ini menunjukkan bahwa persentase sumbangan pengaruh variable.

\section{Hasil uji secara parsial (uji t)}

Uji t dilakukan untuk mengetahui hubungan antara variabel-variabel independen terhdap variabel dependen secara parsial (individu). Dengan menggunakan tingkat signifikan $(\alpha=5 \%)$, jika nilai signifikan $\mathrm{t}>0.05$ maka dan diterima, artinya tidak terdapat pengaruh yang signifikan secara parsial dari variabel independen terhadap variabel dependen. Sebaliknya, jika nilai signifikan $\mathrm{t}<0.05$ maka dan ditolak, artinya terdapat pengaruh yang signifikan secara parsial dari variabel independen dan variabel dependen.

Tabel 14 Hasil Uji Statistik t Coefficients ${ }^{\text {a }}$

\begin{tabular}{|r|c|c|l|l|c|}
\hline \multirow{2}{*}{ Model } & \multicolumn{2}{|c|}{$\begin{array}{c}\text { Unstandardized } \\
\text { Coefficients }\end{array}$} & $\begin{array}{l}\text { Standardized } \\
\text { Coefficient }\end{array}$ & \multirow{2}{*}{ T } & \multirow{2}{*}{ Sig. } \\
\cline { 2 - 4 } & B & Std. Error & Beta & & \\
\hline 1 & 10.402 & 2.328 & & 4.465 & 000 \\
\hline constant) & & & & -1.467 & 146 \\
\hline X1 & -185 & 126 & -154 & 3.302 & 001 \\
\hline X3 & 395 & 120 & 365 & 2.348 & 021 \\
\hline
\end{tabular}

a.Dependent Variabel Y

Sumber : Pengolahan Data SPSS IBM 26

\section{Hasil Uji secara simultan (Uji F)}

Uji F bertujuan untuk menguji masing-masing variabel independen (pemahaman peraturan perpajakan, tarif pajak dan asas keadilan) secara bersama- sama apakah memiliki pengaruh terhadap variabel dependen (kepatuhan wajib pajak). Tingkat signifikan yang digunakan $\alpha=5 \%$ kriteria pengambilan keputusan yaitu:

Tabel 15 Hasil uji Secara Simultan (Uji F)

ANOVA $^{\text {a }}$

\begin{tabular}{|c|c|c|c|c|c|}
\hline Model & $\begin{array}{l}\text { Sum Of } \\
\text { Squares }\end{array}$ & Df & & $\mathbf{F}$ & Sig. \\
\hline Regresion & 207.202 & 3 & 69.067 & 8.397 & 000 \\
\hline Residual & 756.756 & 92 & 8.226 & & \\
\hline Total & 963.958 & 95 & & & \\
\hline
\end{tabular}

a. Dependen Variabel: $\mathrm{Y}$

b. Predictor : (Constant), X3,X1,X2

Sumber : Pengolahan Data SPSS IBM 26 


\section{Pembahasan}

Hipotesis pertama menyatakan bahwa pemahaman peraturan pajak mempunyai pengaruh yang signifikan terhadap kepatuhan wajib pajak dalam membayar pajak. Tabel 12 juga memberikan informasi bahwa pemahaman peraturan pajak memiliki nilai sig. sebesar 0.146 dimana 0,146>0,05 dan nilai $\mathrm{t}$ hitung $-1,467<\mathrm{t}$ tabel 1,986 (daerah kritis tidak berpengaruh adanya nilai negatif) sehingga $\mathrm{HO}$ ditolak dan Ha diterima. Dengan signifikannya pengaruh antara variabel.

\section{Pengaruh Tarif Pajak Terhadap Kepatuhan Wajib Pajak UMKM Dinas Kabupaten Samosir}

Hipotesis kedua menyatakan tarif pajak mempunyai pengaruh yang signifikan terhadap kepatuhan wajib pajak dalam membayar pajak. Tabel 4.10 juga memberikan informasi bahwa tarif pajak memiliki nilai sig. sebesar 0.001 dimana $0,001<0,05$ dan nilai $\mathrm{t}$ hitung $3.302>\mathrm{t}$ tabel 1,986 sehingga H0 ditolak dan Ha diterima. Dengan nilai unstandardized Coefficient 0,395 sehingga dapat disimpulkan bahwa tarif pajak berpengaruh positif signifikan terhadap kepatuhan wajib pajak.

\section{Pengaruh Asas Keadilan Terhadap Kepatuhan Wajib Pajak UMKM Dinas Kabupaten Samosir}

Berdasarkan hasil uji parsial pada tabel 4.10 untuk variabel asas keadilan perpajakan diperoleh koefisien regresi variabel sebesar 0,282. Asas keadilan perpajakan memiliki nilai sig sebesar 0.021 dimana $0,021<0,05$ dan nilai t hitung 2,348>t tabel 1.986 sehingga Ha diterima dan Ho ditolak. Dari penjelasan tersebut dapat di simpulkan bahwa variabel Asas keadilan mempunyai pengaruh signifikan terhadap kepatuhan membayar pajak.

\section{Pengaruh Pemahaman Peraturan Perpajakan, Tarif Pajak dan Asas Keadilan Terhadap Kepatuhan Wajib Pajak UMKM Dinas Kabupaten Samosir}

Tabel 12 menunjukkan nilai $\mathrm{F}$ hitung 8,397 > F tabel 2,703 sedangkan nilai signifikansi adalah sebesar 0,000 dimana nilai $0,000<0,05$. Dengan demikian pemahaman peraturan pajak, tarif pajak dan asas keadilan berpengaruh signifikan terhadap kepatuhan membayar pajak.

\section{KESIMPULAN DAN SARAN}

\section{Kesimpulan}

1. Dari hasil uji F pemahaman peraturan pajak, tarif pajak dan asas keadilan memiliki pengaruh terhadap kepatuhan wajib pajak dalam membayar kewajiban perpajakan Usaha Mikro kecil dan menengah (UMKM) wilayah Kabupaten Samosir.

2. Berdasarkan Uji parsial (uji t) variabel pemahaman peraturan pajak mempunyai pengaruh negatif dan signifikan terhadap kepatuhan wajib pajak. artinya wajib pajak yang paham akan peraturan perpajakan belum tentu patuh terhadap kewajiban perpajakannya.

3. Berdasarkan hasil Uji parsial (uji t) bahwa variabel tarif pajak mempunyai pengaruh positif dan signifikan terhadap kepatuhan wajib pajak. artinya dengan taraf signifikan $0,5 \%$ cukup baik berperan membantu wajib pajak untuk patuh dalam melaksanakan kewajiban perpajakannya.

4. Berdasarkan hasil Uji Parsial (uji t) variabel asas keadilan dengan nilai signifikan sebesar 0.021 dimana $0.021<0.05$ t hitung $2.348>1,986 \mathrm{t}$ tabel. Ini menunjukkan bahwa secara parsial asas keadilan mempunyai pengaruh positif tidak signifikan terhadap kepatuhan wajib pajak. artinya semakin tinggi aspek-aspek keadilan dalam hal 
perpajakan, maka semakin tinggi juga tingkat kepatuhan wajib pajak UMKM dalam melaksanakan kewajiban perpajakannya.

5. Berdasarkan uji $\mathrm{F}$ diperoleh nilai signifikan sebesar $0.000<0.05$ dan $\mathrm{F}$ hitung $8.397>\mathrm{f}$ tabel 2.703 hal ini menunjukkan bahwa pamahaman peraturan pajak, tarif pajak, dan asas keadilan secara simulatan mempunyai pengaruh signifikan terhadap kepatuhan wajib pajak.

6. Hasil dari Adjusted $R$ square sebesar 0.215 hal ini menunjukkan bahwa persentase sumbangn pengaruh variabel depanden (pemahaman peraturan pajak, tarif pajak dan asas keadilan) terhadap variabel independen (kepatuhan wajib pajak pengusaha UMKM Kabupaten Samosir) mampu menjelaskan $21,5 \%$ variabel independen. Sedangkan sisanya sebesar

\section{Saran}

1. Variabel independen yang digunakan dalam penelitian ini memiliki pengaruh sebesar $21,5 \%$ untuk memprediksi kepatuhan kewajiban perpajakan, $78,5 \%$ lainnya dipengaruhi oleh variabel lain. Sehingga untuk Penelitian selanjutnya agar menggunakan variabelvariabel tambahan dalam model penelitian.

2. Untuk Peneliti selanjutnya diharapkan penelitian ini dapat dijadikan sebagai salah satu referensi penelitian tentang pemahaman peraturan pajak, tarif pajak, dan asas keadilan.

3. Wajib pajak diharapkan membayar pajak sesuai dengan peraturan perpajakan yang berlaku karena membayar pajak merupakan salah satu kewajiban terhadap Negara dan digunakan untuk kepentingan umum.

\section{DAFTAR PUSTAKA}

Arikunto. (2009). Dasar Evaluasi Pendidikan. Jakarta: Bumi Aksara.

Evi Rahmawati. (2017). Pemahaman Peraturan Perpajakan, Persepsi Tarif Pajak Dan

Keadilan Perpajakan Terhadap Kepatuhan Wajib Pajak Umkm . Skripsi.Fakultas Ekonomi Dan Bisnis Universitas Islam Negeri Malang

Fakultas Ekonomi. (2013). Buku Pedoman Penulisan Tugas Akhir Jurusan Akuntansi. Medan: Unika St.Thomas.

Fauzi Achmad. (2016). Pengaruh Pemahaman Peraturan Pajak, Tarif Pajak Dan Asas Keadilan Terhadap Kepatuhan Wajib Pajak. Skripsi.Fakultas Ilmu Administrasi Universitas Brawijaya

Ghozali. (2009). Aplikasi Analisis Multivariate Dengan Program Spss. Semarang: Undip.

Mardiasmo. (2011). Perpajakan Edisi Revisi . Yogyakarta: Andi.

Pipit Anisa, Edy Supriyono. (2019). Pengaruh Pemahaman Peraturan Pajak, Tarif Pajak Dan Keadilan Perpajakan Terhadap Kepatuhan Wajib Pajak. Skripsi.

Rochmat Soemitro. (2010). Perpajakan Konsep Teori Dan Isu . Jakarta: Salemba Empat.

Singgih Santoso. (2020). Panduan Lengkap Spss Versi 26. Jakarta: Pt Alex Media Komputindo.

Siti Kurnia Rahayu. (2020). Perpajakan Konsep, Sistem Dan Implementasi, Edisi Revisi. Bandung: Rakaya Sains.

Sugiyono. (2016). Metode Penlitian Kuantitatif, Kualitatif Dan R\&D. Bandung: Rineka Cipta

Budiharto, Widodo.2010.Robotika:Teori + Implementasi. Jogyakarta: Andi 